\title{
LA CUEVA DE NERJA (Malaga, España)
}

\author{
José Ramón Andérica Frías*
}

SUMMARY [The cave of Nerja (Malaga, Spain) ]

The history and the development of the cave of Nerja are here summarized. A short description of the cave with the main goals for the future are also reported.

RIASSUNTO [La grotta di Nerja (Malaga, Spagna) ]

Vengono riassunti la storia e lo sviluppo della grotta di Nerja. Segue una breve descrizione della grotta con $\mathrm{i}$ punti essenziali del futuro sviluppo.

\section{INTRODUCCION}

El presente trabajo pretende ser una carta de presentación en este Congresso sobre cuevas turísticas, al que venimos con la idea de aprender y ponernos de acuerdo para mejorar la gestión y conservación de las cuevas turísticas. Por ello hemos pensado, ayudados $p$ or las imágenes, hacer un recorrido breve por la Cueva y al final hacernos unas interrogantes.

La Cueva de Nerja fue descubierta en el año 1959 casualmente por unos júvenes de la vecina localidad de Maro. Desde el primer momen to de su descubrimiento se vió la importancia del monumento y se creó para su conservación un Patronato que, desde entonces, bajo la presidencia de los Gobernadores Civiles de la previncia de Málaga, han potenciado el estudio de los aspectos geológicos y arqueológicos y han preparado el interior y exterio de la Cueva, para las numerosas personas que desde el primer momento la han visitado y qu e, en la actualidad, podemos cifrar en unas quinientas mil al año.

Tiene la Cueva una Comisión Científica Asesora que en los últimos años ha impulsado los estudios, fruto de ello ha sido la publicación en el año 1986 del primer volumen de una colección editada por el Patronato de la Cueva: «La Prehistoria de la Cueva de Nerja. Málaga»; una serie de estudios dirigidos por los catedráticos Jordá Cerdá, de la Universidad de Salamanca y Pellicer, de la Universi dad de Granada.

Está próximo a salir el número dos de la colección con los trabajos que dirigen los doctores Marí Girón, de la Universidad de Málaga y Hoyos, del Museo Nacional de Ciencias Naturales de Madrid.

Yo quiero, desde aquí, invitar a todos los que quieran conocer nuestra Cueva y, a tal efecto, hacemos una invitación para celebrar una reunión en

\footnotetext{
* c/o Patronato de la Cueva de Nerja, Carretera de Maro s/n, E-29787 NERJA (Malaga) España
} 
Nerja en una fecha próxima. Ahora ofrezco la posibilidad de un recorrido por las salas ayudado por las diapositivas, haciendo la observación preliminar de que la Cueva se divide en dos partes, la primera acondicionada para la visita turística y la segunda «galerías altas» cerradas al público. La gran diferencia entra una y otra ya la puenden imaginar: la primera, visitable por el gran público, ha sufrido con la iluminación artificial, con la presencia de miles de visitantes, con el peligroso aumento de cantidad de $\mathrm{CO}_{2}$, sobreto en el periodo estival y con un horario excesivo de iluminación; la segunda ha permanecido cerrada desde su descubrimiento y no está acondicionada para la visita turística, como luego veremos, es mucho mayor que la primera en longitud, altura, en formaciones geológicas originales y es donde se encuentran las pinturas rupestres mejor conservadas.

\section{RECORRIDO}

Galerías visitables.

La entrada y la salida que hoy se utilizan, no fueron las que utilizaron descubridores, que se encuentran muy próximas. La entrada antigüa que en un momento se cerró por causas naturales, es la que hoy se utiliza, después de una serie de estudios arqueológicos. Se atraviesan unas salas pequeñas conocidas con los nombres del «belén», donde se encuentran expuestas en unas vitrinas algunas mues tras de restos encontrados en las diversas excavaciones; y del "colmillo», con unos paneles informativos; después de un pasillo se 1 lega una balconada desde la que se divisa una bellísima perpestiva de la sala de «la Cascada» o del «Ballet», asi llamada por celebr arse en ella, todos los años, durante el mes de julio, unos festivales internacionales de música y danza.

La altura de techo en esta sala es de veinticinco metros y el ancho de treinta metros; a continuación la sala de los «fantasmas» y a través de los «organos» llegamos a la grandiosa sala del «cataclismo», con la gran columna en el centro de 32 metros de altura y 13 de diámetro. Esta sala supera, en algunos puntos los 35 metros de altura. En linea recta, la Cueva visitable sería de 200 metros.

\section{Galerias altas.}

No están preparadas para la visita turística y son aproximadamente el doble en tamaño que las galerías visitables. La salas reciben los nombres de : «Las columnas de Hércules», «Camarin de los pisciformes», «Los niveles», «La lanza», «La montaña»

No es mi intención agotar al auditorio con subjetivas alabanzas sobre la Cueva de Nerja y les remito a una biografía, creo que ya extensa para los treinta años que lleva la Cueva descubierta. 


\section{EL FUTURO}

Por último y como apunté al comienzo, el intercambio que solicito y que esbozo en los siguientes puntos:

a) Apoyar y reforzar la Asociación Internacional de Cuevas Turísticas.

b) Como vehículo de intercambio editar una publicación periódica.

c) Intercambiar publicaciones.

d) Elaborar, mediante una encuesta, un inventario europeo de cuevas turísticas

e) Ofrecer las instalaciones de la Cueva de Nerja y la hospitabilitad de la localidad de Nerja en Málaga, para un futuro, no lejano encuentro entre los socios y amantes de las cavidades naturales. 